\title{
Gender Comparison of Communication Skills of Nursing Students: Video Analysis of Standardized Patient Interview
}

\author{
Kim Mi-Won ${ }^{1}$ and Lee Hee-Joo ${ }^{2}$ \\ Department of Nursing, Sang-Myung University, Korea \\ ${ }^{1}$ kmw@smu.ac.kr, ${ }^{2}$ foremost@smu.ac.kr
}

\begin{abstract}
The purpose of this study was to investigate gender differences in communication skills of nursing students. The subjects of this study were 99 nursing students in a university. Data were collected by recording the interview process conducted by nursing students with the standardized patients and transcripts were made from the recorded video. To evaluate student's communication skills, researchers analyzed video and transcripts objectively. Female students scored significantly higher than male students in listening skills $(p=.002)$. Among the items assessing poor interview attitudes, too much focus on writing records $(61 \%)$ was the most frequent. Therefore, the findings suggest an importance to find ways to improve the listening skills among the communication skills under the situation in increasing number of male nursing students.
\end{abstract}

Keywords: Gender, Comparison, Communication, Skills, Standardized, Patient, Interview, Video analysis

\section{Introduction}

Effective communication with patients is an important skill for nurses to achieve quality care [1][2] and it is considered very important for patients' healing process [1]. However, due to the lack of communication skills of nurses, patient-nurse communication is often reported to be inefficient [3], and this is especially true with novice nurses [4].

Meanwhile, there has been an increase in the proportion of male nurses in South Korea. The number of male students pursuing nursing degree in 2000 was only 662 which accounted for $1.8 \%$ of all nursing students, but in 2011, the number increased to 7,968 which is $13 \%$ of all nursing students. This is almost 12-fold increase in the number [5]. The results from previous studies showed that female students scored higher in cognitive empathy and emotional response than male students [6] and in terms of communication skills, female students showed higher scores than male students in items including "awareness", "comfort", and "acceptance" [7]. Therefore, it is thought that there will a difference in the communication skills between female students and male students.

To develop natural and effective communication skills in actual situation, the systematic education and trainings as well as the various teaching and learning strategies are necessary [8][9]. There are some self-report questionnaires designed to assess communication skills [9][10], but one of the ways to effectively assess communication skills is to use standardized

Article history:

Received (October 13, 2017), Review Result (November 24, 2017), Accepted (December 23, 2017) 
patients. This method is considered a valid evaluation tool that enables objective evaluation of nursing students' communication skills in actual clinical situation [11].

Therefore, in this study, we tried to examine the nursing students' communication skills in 'interview for collecting clinical history' which is one of the basic communication situations for nurses, and to explore the gender difference in communication skills. We developed a tool to evaluate communication skills through objective observation. The purpose of this study was to investigate the gender differences in nursing students and to reflect them in the curriculum so that it can supplement the communication skills that each gender lacks. Also, the results of this study could be used for developing the program to improve the interview skills.

\section{Method}

\subsection{Research design}

In this study, we compared the differences in communication skills between male and female nursing students. The subjects of this study were 99 nursing students who were taking "Practices in Health Examination" course in a university at C city.

\subsection{Research tools}

Communication skill assessment tool was developed based on the interview assessment tool by Nam Kung and Kim [12]. We revised the contents and divided them into conversation opening, relationship formation, information collection and conversation closing. The assessment tool had 9 sub-domains and had total 28 items. Each item was evaluated on three scales - performed, insufficient, and not performed - which were converted into 2,1 , and 0 points, respectively. The reliability of the instrument in this study was .81 .

\subsection{Development of the clinical scenario}

The clinical scenario was set as the interview process for collecting the clinical history for the varicose vein patient who is visiting the hospital for the first time. Using 4 domains and 9 procedures, following factors were evaluated: greeting, confirmation of the main complaint, the follow-up questions about the patient's chief complaint, specific questions on past clinical history, social history, and family history, maintenance of the flow of interview, understanding of nonverbal expression, empathy and psychological support, use of easy terminology, closing remarks, and attitudes. To evaluate such factors, appropriate questions and answers were placed in the scenario.

\subsection{Research procedure}

Research procedures included scenario development, recruitment of standardized patients from the Theater and Film Department and training, development of communication skill assessment tool, video recording and making transcript of the interview process in Practices in Health Examination class, evaluation of videos and transcripts using communication skill assessment tool (objective evaluation).

\subsection{Data collection}


Videos were recorded from October 2016 to April 2017. Video and transcript analyses were conducted from April 2017 to August 2017.

\subsection{Data analyses}

Collected data were analyzed using SPSS 21.0 statistics program at the .05 significance level. The general characteristics of the participants were analyzed with frequency analysis to calculate frequency and percentage. The communication skills of male and female students were tested with t-test and Mann-Whitney test.

\subsection{Research ethics}

This research was approved by S University Institutional Review Board (SMUIRB-AP2016-004). The research objectives and procedures were explained to all participants and consent form was acquired from all participants before the participation.

\section{Result}

\subsection{General characteristics of the participants}

A total of 99 students were included in this study. Among them, 81 students $(81.8 \%)$ were females and 18 students $(18.2 \%)$ were males. In terms of age, 47 students $(47.5 \%)$ were under the age of 20, 35 students (35.4\%) were aged between 21 and 22, and 17 students (17.2\%) were aged 23 or over [Table 1].

Table 1. General characteristics of the participants $(n=99)$

\begin{tabular}{|c|c|c|c|}
\hline Category & & Frequency $(\mathrm{n})$ & Percentage (\%) \\
\hline \multirow{3}{*}{ Sex } & Female & 81 & 81.8 \\
\cline { 2 - 4 } & Male & 18 & 18.2 \\
\cline { 2 - 4 } & Total & 99 & 100.0 \\
\hline \multirow{4}{*}{ Age } & 20 or less & 47 & 47.5 \\
\cline { 2 - 4 } & $21-22$ & 35 & 35.4 \\
\cline { 2 - 4 } & 23 or more & 17 & 17.2 \\
\cline { 2 - 4 } & Total & 99 & 100.0 \\
\hline
\end{tabular}

\subsection{Gender differences in communication skills}

Communication skills were significantly higher for female students than for male students in listening skills $(\mathrm{p}=.002)$. There was no significant difference in the other items, but male students had numerically higher scores in conversation opening, asking first question, and conversation closing than female students. Female students scored numerically higher in information collection, interview organization, empathetic support, understanding patient's point of view, and attitude than male students [Table 2].

\subsection{Gender differences in poor nonverbal interview attitudes}

Among the items assessing poor nonverbal interview attitudes, $61 \%$ focused too much on writing records, $50 \%$ showed meaningless smile, and $27 \%$ repeated meaningless motion. Both male $(50 \%)$ and female $(63 \%)$ students showed the highest percentage of too much focus on 
writing records. There was no significant difference between female and male students in eye contact, pronunciation, response, facial expression, motion, meaningless smile, and writing attitude [Table 3]. Transcript analysis showed that percentage of asking open-ended question was $35.71 \%$ and $42.71 \%$ for female and male students, respectively.

Table 2. Gender differences in communication skills $(n=99)$

\begin{tabular}{|c|c|c|c|c|c|c|c|c|}
\hline & \multirow[b]{2}{*}{ Item } & \multirow{2}{*}{$\begin{array}{c}\text { Total } \\
\text { Mean } \\
( \pm \text { SD) or } \\
\mathrm{n}(\%)\end{array}$} & \multicolumn{2}{|c|}{ Female } & \multicolumn{2}{|c|}{ Male } & \multirow[b]{2}{*}{$\begin{array}{c}\text { Mann- } \\
\text { Whitney U }\end{array}$} & \multirow[b]{2}{*}{$p$} \\
\hline & & & $\begin{array}{c}\text { Mean } \\
( \pm \mathrm{SD}) \\
\text { or } \mathrm{n}(\%)\end{array}$ & $\begin{array}{l}\text { Mean } \\
\text { ranking }\end{array}$ & $\begin{array}{c}\text { Mean } \\
( \pm \mathrm{SD}) \\
\text { or } \mathrm{n}(\%)\end{array}$ & $\begin{array}{l}\text { Mean } \\
\text { ranking }\end{array}$ & & \\
\hline \multirow{10}{*}{$\begin{array}{c}\text { Communication } \\
\text { skills } \\
\text { (Objective } \\
\text { evaluation) }\end{array}$} & $\begin{array}{c}\text { Conversation } \\
\text { opening }\end{array}$ & $\begin{array}{c}1.24 \\
( \pm 0.45)\end{array}$ & $\begin{array}{c}1.23 \\
( \pm 0.44)\end{array}$ & 48.54 & $\begin{array}{c}1.29 \\
( \pm 0.52)\end{array}$ & 56.56 & 611.00 & .270 \\
\hline & $\begin{array}{l}\text { Asking first } \\
\text { question }\end{array}$ & $\begin{array}{c}1.08 \\
( \pm 0.42)\end{array}$ & $\begin{array}{c}1.07 \\
( \pm 0.42)\end{array}$ & 49.22 & $\begin{array}{c}1.11 \\
( \pm 0.44)\end{array}$ & 53.53 & 665.500 & .462 \\
\hline & $\begin{array}{c}\text { Information } \\
\text { collection }\end{array}$ & $\begin{array}{c}0.91 \\
( \pm 0.37)\end{array}$ & $\begin{array}{c}0.91 \\
( \pm 0.37)\end{array}$ & 47.32 & $\begin{array}{c}0.91 \\
( \pm 0.41)\end{array}$ & 48.25 & 670.500 & .895 \\
\hline & $\begin{array}{c}\text { Interview } \\
\text { organization }\end{array}$ & $\begin{array}{c}0.72 \\
( \pm 0.41)\end{array}$ & $\begin{array}{c}0.74 \\
( \pm 0.43)\end{array}$ & 50.70 & $\begin{array}{c}0.60 \\
( \pm 0.32)\end{array}$ & 41.53 & 576.50 & .204 \\
\hline & Listening & $\begin{array}{c}1.11 \\
( \pm 0.61)\end{array}$ & $\begin{array}{c}1.17 \\
( \pm 0.59)\end{array}$ & 53.01 & $\begin{array}{c}0.81 \\
( \pm 0.64)\end{array}$ & 36.47 & 485.50 & $.002^{*}$ \\
\hline & $\begin{array}{l}\text { Empathetic } \\
\text { support }\end{array}$ & $\begin{array}{c}0.78 \\
( \pm 0.38)\end{array}$ & $\begin{array}{c}0.79 \\
( \pm 0.38)\end{array}$ & 50.66 & $\begin{array}{c}0.72 \\
( \pm 0.41)\end{array}$ & 47.03 & 675.50 & .619 \\
\hline & $\begin{array}{c}\text { Understanding } \\
\text { patient's point } \\
\text { of view }\end{array}$ & $\begin{array}{c}0.73 \\
( \pm 0.54)\end{array}$ & $\begin{array}{c}0.75 \\
( \pm 0.51)\end{array}$ & 50.97 & $\begin{array}{c}0.65 \\
( \pm 0.66)\end{array}$ & 45.64 & 650.50 & .460 \\
\hline & $\begin{array}{c}\text { Conversation } \\
\text { closing }\end{array}$ & $\begin{array}{c}0.45 \\
( \pm 0.53)\end{array}$ & $\begin{array}{c}0.44 \\
( \pm 0.51)\end{array}$ & 49.72 & $\begin{array}{c}0.50 \\
( \pm 0.59)\end{array}$ & 51.25 & 706.50 & .826 \\
\hline & Attitude & $\begin{array}{c}1.29 \\
( \pm 0.60)\end{array}$ & $\begin{array}{c}1.31 \\
( \pm 0.60)\end{array}$ & 50.58 & $\begin{array}{c}1.19 \\
( \pm 0.60)\end{array}$ & 44.72 & 634.00 & .414 \\
\hline & Total & $\begin{array}{c}1.01 \\
( \pm 0.27)\end{array}$ & $\begin{array}{c}1.02 \\
( \pm 0.27)\end{array}$ & 51.01 & $\begin{array}{c}0.96 \\
( \pm 0.28)\end{array}$ & 45.44 & 647.00 & .457 \\
\hline
\end{tabular}

\section{Discussion}

Comparison of communication skills in male and female students showed that female students scored significantly higher in listening skills $(\mathrm{p}=.002)$ among nine communication skill area than male students. There were no significant results in the other items. So, it is hard to say that there is a difference in the communication skills of male and female. Such findings are in contrast to the previous study [13] which compared dental hygiene college students' communication ability, and showed that communication ability was significantly higher in female students than in male students according to gender.

In addition, findings are in contrast to another research [6] which studied gender difference in empathizing-systemizing traits in medical students and showed that cognitive empathy and the emotional response were significantly higher in the female students than in male students. In another study that compared communication skills [7], female students scored significantly higher than male students in "awareness", "comfort", and "acceptance". But in our study, direct comparisons with previous studies may be difficult because there are few papers comparing the communication skills of male and female nursing students with the 
objective evaluation of the instructor as done in this study. However, according to previous study, the difference in empathy between males and females may be due to gender differences in brain structure or disposition [6].

Table 3. Gender differences in poor nonverbal interview attitudes $(n=99)$

\begin{tabular}{|c|c|c|c|c|c|c|}
\hline & & \multirow[b]{2}{*}{$\begin{array}{c}\text { Total } \\
\text { Frequency } \\
(\%)\end{array}$} & \multicolumn{2}{|c|}{ Sex } & \multirow[b]{2}{*}{$X^{2}$} & \multirow[b]{2}{*}{$\mathrm{P}$} \\
\hline & & & $\begin{array}{c}\text { Female } \\
\text { Frequency } \\
(\%)\end{array}$ & $\begin{array}{c}\text { Male } \\
\text { Frequency } \\
\quad(\%)\end{array}$ & & \\
\hline \multirow{2}{*}{ Eye contact } & Yes & $\begin{array}{c}88 \\
(88.9)\end{array}$ & $\begin{array}{c}72 \\
(88.9)\end{array}$ & $\begin{array}{c}16 \\
(88.8)\end{array}$ & \multirow{2}{*}{2.116} & \multirow{2}{*}{.225} \\
\hline & No & $\begin{array}{c}11 \\
(11.1)\end{array}$ & $\begin{array}{c}9 \\
(11.1)\end{array}$ & $\begin{array}{c}2 \\
(11.2)\end{array}$ & & \\
\hline \multirow{2}{*}{ Pronunciation } & Accurate & $\begin{array}{c}83 \\
(83.8)\end{array}$ & $\begin{array}{c}68 \\
(84.0)\end{array}$ & $\begin{array}{c}15 \\
(83.3)\end{array}$ & \multirow{2}{*}{.066} & \multirow{2}{*}{1.000} \\
\hline & Inaccurate & $\begin{array}{c}16 \\
(16.2)\end{array}$ & $\begin{array}{c}13 \\
(16.0)\end{array}$ & $\begin{array}{c}3 \\
(16.7)\end{array}$ & & \\
\hline \multirow{2}{*}{ Response } & $\begin{array}{l}\text { Appropriate } \\
\text { response }\end{array}$ & $\begin{array}{c}83 \\
(83.8)\end{array}$ & $\begin{array}{c}66 \\
(81.4)\end{array}$ & $\begin{array}{c}17 \\
(94.4)\end{array}$ & \multirow{2}{*}{1.689} & \multirow{2}{*}{.295} \\
\hline & No response & $\begin{array}{r}16 \\
(16.2)\end{array}$ & $\begin{array}{r}15 \\
(18.6)\end{array}$ & $\begin{array}{c}1 \\
(5.6)\end{array}$ & & \\
\hline \multirow{2}{*}{$\begin{array}{c}\text { Facial } \\
\text { expression }\end{array}$} & Yes & $\begin{array}{c}81 \\
(81.8)\end{array}$ & $\begin{array}{c}66 \\
(81.4)\end{array}$ & $\begin{array}{c}15 \\
(83.3)\end{array}$ & \multirow{2}{*}{.480} & \multirow{2}{*}{.496} \\
\hline & No & $\begin{array}{c}18 \\
(18.2)\end{array}$ & $\begin{array}{c}15 \\
(18.6)\end{array}$ & $\begin{array}{c}3 \\
(16.7)\end{array}$ & & \\
\hline \multirow{2}{*}{ Motion } & $\begin{array}{c}\text { No meaningless } \\
\text { motion }\end{array}$ & $\begin{array}{c}72 \\
(72.7)\end{array}$ & $\begin{array}{c}60 \\
(74.1)\end{array}$ & $\begin{array}{c}12 \\
(66.6)\end{array}$ & \multirow{2}{*}{.332} & \multirow{2}{*}{.573} \\
\hline & $\begin{array}{l}\text { Meaningless } \\
\text { motion }\end{array}$ & $\begin{array}{c}27 \\
(27.3)\end{array}$ & $\begin{array}{c}21 \\
(25.9)\end{array}$ & $\begin{array}{c}6 \\
(33.4)\end{array}$ & & \\
\hline \multirow{2}{*}{$\begin{array}{l}\text { Meaningless } \\
\text { smile }\end{array}$} & $\begin{array}{c}\text { No meaningless } \\
\text { smile }\end{array}$ & $\begin{array}{c}50 \\
(50.5)\end{array}$ & $\begin{array}{c}41 \\
(50.6)\end{array}$ & $\begin{array}{c}9 \\
(50,0)\end{array}$ & \multirow{2}{*}{.119} & \multirow{2}{*}{.799} \\
\hline & $\begin{array}{l}\text { Meaningless } \\
\text { smile }\end{array}$ & $\begin{array}{c}49 \\
(49.5)\end{array}$ & $\begin{array}{c}49 \\
(49.4)\end{array}$ & $\begin{array}{c}9 \\
(50.0)\end{array}$ & & \\
\hline \multirow{2}{*}{ Writing attitude } & $\begin{array}{l}\text { Not too much } \\
\text { focus on writing }\end{array}$ & $\begin{array}{c}39 \\
(39.4)\end{array}$ & $\begin{array}{c}30 \\
(37.0)\end{array}$ & $\begin{array}{c}9 \\
(50.0)\end{array}$ & \multirow{2}{*}{1.04} & \multirow{2}{*}{.429} \\
\hline & $\begin{array}{c}\text { Too much focus } \\
\text { on writing }\end{array}$ & $\begin{array}{c}60 \\
(61.6)\end{array}$ & $\begin{array}{c}51 \\
(63.0)\end{array}$ & $\begin{array}{c}9 \\
(50.0)\end{array}$ & & \\
\hline
\end{tabular}

Therefore, it is necessary to acknowledge such gender differences and to make efforts to improve the educational effect on both male and female nursing students. Moreover, the ability of nurses to communicate in clinical settings is very important, suggesting that this study should consider the ways to improve the communication and listening skills under the situation in increasing number of male nursing students.

On the other hand, the items assessing poor nonverbal interview attitudes, too much focus on writing records $(61 \%)$ was the most frequent for both male $(50 \%)$ and female $(63 \%)$ students, suggesting that continuous training is needed to correct nonverbal behaviors that may have negative effects. 
Gender Comparison of Communication Skills of Nursing Students: Video Analysis of Standardized Patient Interview

\section{References}

[1] N. Bowles, C. Mackintosh, and A. Torn, "Nurses' communication skills: An evaluation of the impact of solution-focused communication training," Journal of Advanced Nursing, vol.36, pp.347-354, (2001)

[2] L.S.C.H. Thorsteinsson, "The quality of nursing care as perceived by individuals with chronic illnesses: The magical touch of nursing," Journal of Clinical Nursing, vol.11, pp.32-44, (2002)

[3] D. Kunyk and J.K. Olson, "Clarification of conceptualizations of empathy," Journal of Advanced Nursing, vol.35, no.3, pp.317-325, (2001)

[4] M. Yi, S.E. Oh, M.R. Eom, H.S. Kim, K.J. Cho, J.S. Choi, and K.S. Lee, "Characteristics of nursing performance based the expertise among ICU nurses," Journal of Korean Academic Adult Nursing, vol.14, no.2, pp.296-305, (2002)

[5] H.S. Kim, "The Korean nurses association news," Retrieved from http://www.nursenews.co.kr/Article/ArticleDetailView.asp?typ=3\&articleKey=1455, (2013)

[6] S.Y. Lim, "The relationship between brain type of the empathizing-systemizing traits and subjective quality of life of medical students," M.S. thesis, Ewha Womans University, Seoul, Korea, (2015)

[7] J.W. Park and N.S. Ha, "Communication apprehension and performance of using communication skills according to nursing students' enneagram personality types,” The Korean Journal of Stress Research, vol.22, no.4, pp.169-180, (2014)

[8] E.J. Song, "The effects of a communication training program on communication and interpersonal relationship for student nurses in clinical practice," The Korean Journal of Fundamentals Nursing, vol.13, no.3, pp.467-473, (2006)

[9] Y.S. Park, S.B. Im, and H.S. Kim, "The effects of reinforced self-understanding in nursing communication curriculum," Journal of Korean Academy of Psychiatric and Mental Health Nursing, vol.18, no.3, pp.361$368,(2009)$

[10] S.H. Bae and J.S. Park, "The Recognition of Achievement and Importance of Nursing Program Outcome among Nursing Students," The Journal of Korean Academic Society of Nursing Education, vol.19, no.1, pp.203-214, (2013)

[11] J.A. Vessey and K. Huss, "Using standardized patients in advanced practice nursing education," Journal of Professional Nursing, vol.18, no.1, pp.29-35, (2002)

[12] J. Nam Kung and J.H. Kim, "The Developing and Validation of Communication Ability Scale," The Journal of Creativity Education, vol.10, no.1, pp.85-109, (2010)

[13] S.J. Kim and H.H. Kim, "Impact of Communication Competence and Empathy Abilities on Interpersonal Relationship Abilities among Dental Hygiene Students,” Journal of Dental Hygiene Science, vol.13, no.3, pp.304-313, (2013) 